\title{
7. From billionaires to the bottom billion: who's making education policy for the poor in emerging economies?
}

\section{Carol Anne Spreen and Sangeeta Kamat}

Privatization of education is at a new and dangerous phase, particularly in emerging economies of Africa, Asia and Latin America, where multinational companies have their sights set on the profit potential of 'education markets' in these regions. The global market for education is estimated to reach $\$ 5$ trillion, with much of this growth expected in Asia and Africa, with many of their countries having the highest proportion of school-age children in the world. ${ }^{1}$ While this chapter is based on research conducted in India, ${ }^{2}$ we find parallel trends of global corporate investment and profit-seeking ventures in the school sector in other developing and emerging economies. Our research focused on the city of Hyderabad in southern India that has the highest rates of school privatization in the country and is also home to technology giants such as Microsoft and Google. We made site visits to private schools and government schools in low-income neighbourhoods, interviewed principals and proprietors, consultants and start-up firms that are engaged in the design and delivery of services and

1 The IBIS estimates offer a glimpse of the market for e-learning (beyond US borders), serving 1.4 billion students and 62.5 million educators according to an analysis by an international investment bank that advises companies on educational technology (EdWeek Market Brief, 7 February 2013).

2 For a comprehensive report of our research and findings, see Education International (2016). 
products, and spoke with parents, education activists and government school teachers. One of the primary findings of our study is the extent to which the global technology industry is leading the 'scaling up' of the for-profit education sector globally, with its eyes set on the un-tapped market of parents and their over-burdened governments in India and Anglophone parts of Africa. While there are varied entry points for private sector approaches in education, it is (so-called) 'low-fee' private schools rooted in e-learning technologies that are of primary interest to multinational companies that are active in this sector. Alarmingly, children and families in some of the world poorest communities are the primary target of this industry, with shareholder reports referring to the 'untapped potential of the world's bottom billion' (Bridge International Academies, n.d.).

This hugely profitable market of the edu-solutions industry has been well documented elsewhere (see, for instance, Junemann and Ball, 2015; Olmedo, 2013; Hogan, Sellars and Lingard, 2015; Verger 2016), and Nambissan's work in particular has been valuable in tracking the evolution of this industry in Hyderabad starting from the early 2000s to the present (see Nambissan 2014, 2012a; Nambissan and Ball, 2011). Our study corroborates and extends Nambissan's research on Hyderabad as an important site to understand the dynamics of for-profit education in emerging economies. Our research uncovers the powerful nexus between global tech companies and hedge fund investors, conservative think tanks, and edu-businesses in establishing a profitable education services market (see also Nambissan, 2012a, 2014) combined with the desires and aspirations of the marginalized to seek better education opportunities. Similar to Nambissan (2012a), our research shows that early efforts to 'scale up' Hyderabad's independently owned and dispersed network of low-fee private schools were initially unsuccessful due to government regulations and limited payer abilities, but other new (largely unregulated) markets were also created.

In many ways India's RTE Act (2010) has made multinational corporations wary of investing and scaling up LFPS and this has led investors and companies to create new markets in areas that are unregulated and virtually untapped, such as pre-schools and tutoring services for low-income families. Other strategies have been to create public-private partnership or PPPs with local governments (as in the case of Bridge International Academies). Significantly, 
investment by these players in technology-based education solutions outside of regulatory frameworks (including developing curricula and classroom resources, assessment and testing systems, training for teachers and education industry leaders, and even virtual or online schooling) have flourished. These products and services, with links to multinational corporations and investors, have immediate global scalability that can potentially redefine education in previously unimaginable ways. The central question is: whose interests are served by these new edu-solutions providers?

Our research explains why Hyderabad is a choice destination for investors and companies in their 'market making' efforts. In the 1990s, Hyderabad was established as an 'outpost' of the global outsourcing economy and became a hub for software developers, call centres and 'back office' operations for leading multinationals including Google, Microsoft and Amazon (Biao, 2006; Upadhyay and Vasavi, 2008). In the post-2008 global recession, some part of the software sector and outsourcing is being redirected toward developing and scaling up the edu-business market. Hyderabad, with its already established software economy and a surplus of skilled labour in the tech industry, provides the perfect 'ecosystem' for the edu-solutions industry. From the point of view of market efficiency therefore, it is logical that Hyderabad is an attractive site for venture philanthropy, global tech companies and private equity firms looking to make 'impact investments' in the edu-solutions market. E-learning companies poised to benefit from this market including content and assessment corporations like Pearson, mobile network firms, and companies that provide toolkits and tablets have been focusing on these products for years, with India's software industry as a key developer and recipient (Cave and Rowell, 2014b). The mobile education market is predicted to be worth $\$ 75$ billion worldwide by 2020, and market for devices like learning tablets is set to be worth $\$ 32$ billion (see Education International, 2016). It is ripe for expansion in India. Estimates from rating agencies place the potential value of India's education market at $\$ 110$ billion (Shinde, 2013; Chatterji, 2010; India Brand Equity Foundation, 2016). Multinational technology giants such as Microsoft, Dell, eBay and Facebook are making significant investments in this sector in order to leverage this market and provide a comprehensive set of products and services including data management, assessment systems, curricula, teacher training, online courses, and 
virtual schools, that eventually aim to make the state redundant as an educational provider.

In mapping the evolution and merging of e-learning with private schools for the poor our study shows that as these products become institutionalized in the management and governance of schools (e.g., school accreditation, certification requirements or becoming a 'brand' of some sort), their market expands and prices for products and services increase significantly. We found that multinational corporations are not merely benignly selling products and services to open markets; they are also actively engaged in lobbying for education policies that benefit their bottom line. Most importantly, their 'profits' are derived not from some benign 'market' of middle-class consumers, but from fees paid by poor families and government education funding!

While we believe that e-learning services could provide more democratic, freer, universally accessible forms of education, the reality of for-profit education services is that they support a tiered system based on individuals' ability to pay. The world's largest multinational education corporation, Pearson, operates in 70 countries, positioning itself as the world's education service provider, often using technology-based one-stop-shop programmes from curriculum and assessment, to teacher training and data-based decision-making software. Pearson has entered emerging economies (e.g., India and the Philippines) through the Pearson Affordable Learning Fund (PALF), a venture capital investment fund. As it headlines on its website, PALF 'makes significant minority equity investments in for-profit companies to meet the growing demand for affordable education across the developing world'. ${ }^{3}$

Bridge International Academies (BIA) founded by an American couple is one of the most ambitious for-profit education companies to emerge in recent years. Financed by Pearson, billionaires Gates, Zuckerberg and Omidyar, and aid/development organizations such as DFID-UK and the World Bank, the Bridge model of 'School in a Box' promises huge profits through rapid expansion of a low resource, standardized and scalable model of schooling that leverages the technology assets of the investors themselves.

3 See https://www.pearson.com/corporate/sustainability/sustainability-stories. html and https://www.cbinsights.com/investor/pearson-affordable-learning for PALF's for-profit investments in education. Retrieved on 20 May 2018. 
The projected earnings in BIA's 2015 report to shareholders (BIA Franchisee Report, 2015, in BIA, n.d.) assures a billion dollars in revenue over a ten-year period. The same report maps the first phase of market expansion of BIA based on a PPP model of governments in Liberia, Kenya and India outsourcing their public schools to BIA. It bases this projected expansion on an assessment of 800 million pre-primary and primary school aged pupils in these countries living on less than $\$ 2$ per person per day and 70 per cent of their parents seeking 'a better alternative' schooling, most already committed to private schooling but in 'cottage industry' schools. The document claims there is room for an 'aggressive, technology-leveraged, data-driven R\&D, scaled approach'.

Through these and other public-private partnership (PPP) approaches, governments are beginning to outsource education systems (instead of investing in teachers and infrastructure), which has enabled corporations like Pearson to make considerable profits from public sector investments. Though outsourcing involves longer-term relationships with higher risks to governments (as opposed to subcontracting, for instance), it has become accepted practice within the education aid and development model. This fiscal impetus has impacted education delivery, shifting education policy and planning from a national to a global endeavour that is increasingly shaped by businesses not educators.

Moreover our research suggests that throughout the world a wide array of technology-based education reforms are being introduced lacking any evidence base. In many ways, new education technologies have redesigned the delivery of education - standardizing and commoditizing education, reducing educational processes and student-teacher relationships to easily quantifiable and recorded forms, and distancing educational professionals from the process of educational engagement (ultimately deprofessionalizing and deskilling the teaching profession). By tracing the evolution of the so called 'edu-solutions' industry in India, we demonstrate how technology, big data, Artificial Intelligence, virtual learning, and standardized assessment/data systems have served as a conduit for private interests entering the classroom. The rest of this chapter summarizes what has been the perfect storm in one of India's high-tech hubs - Hyderabad - where the technology industry attempts to meet the needs and desires of aspiring poor families at the door of a growing low-fee private school industry targeting 
India's poor. We then shed light on some of the big players of the Global Education Industry and their approaches and impacts on the public education sector in this part of India.

Lastly, our study underscores that the privatization of education also undermines the right to education, diverting much-needed government funding to the private sector instead of the better provisioning of public schools by improving facilities, resources, and support for schools and teachers. ${ }^{4}$ Through their global influence in policy and planning, multinational corporations are not only beginning to control the content of the curriculum and testing in countries, they also make decisions about who teaches and under what conditions, and have begun to replace qualified teachers with untrained (and underpaid) teachers ${ }^{5}$ using tablets or mobile-based scripted curricula. Despite all the evidence indicating that the application of market principles to the provision of education has a negative impact on students by deepening segregation and inequality, and undermining quality, many governments are complicit in what amounts to a de facto dismantling of public education (Spreen and Vally 2014; Härmä, 2009, 2011).

\section{THE PERFECT STORM: NEOLIBERAL REFORMS AND DISINVESTMENT IN PUBLIC EDUCATION}

In India, the decline of public education and the concomitant growth of private education can be traced to three main factors. First, the meagre education budget does not match demand. India has the largest youth demographic in the world, with half the

4 See Global Section: the School Fee Abolition Initiative (SFAI), report from The United National Girls' Education Initiative (UNGEI). Retrieved from http:// www.ungei.org/infobycountry/247_712.html on 4 June 2018; Privatisation in Education: Global Trends and Human Rights Impact; report from the Right to Education Project (RTE) (2014), Retrieved from http://www.right-to-education. org/resource/privatisation-education-global-trends-human-rights-impact on 4 June 2018; and Working for the Many: Public Services Fight Inequality, report from Oxfam International (2014). Retrieved from https://policy-practice.oxfam.org.uk/ publications/working-for-the-many-public-services-fight-inequality-314724 on 4 June 2018.

5 Similar trends have been identified in other emerging economies such as the Philippines, Ghana and South Africa. See Riep (2015); Spreen and Vally (2014) for details of the GEI in these countries. 
country's population of 1.2 billion under the age of 25 , but the education budget hovers at around 3.8 per cent of gross national product $(\mathrm{GNP})^{6}$ (Varma, 2017). In 1968, the Indian state had committed to 6 per cent of GNP for its education budget, a target unfulfilled to this day (Tilak, 2009, 2006). A lack of political will to finance public education has legitimated the corporate sector's role in fulfilling unmet demand in education. Second, in 1991, the Indian state launched far-reaching reforms to liberalize, deregulate, and privatize the public sector, including social sectors such as health care and education (Nambissan, 2010; Nayyar, 2008; Venkatnarayanan, 2015). As a result, state governments divested themselves from government schools, shrinking the size of the sector and adversely impacting quality. To conclude from this that poor people are 'voting with their feet' as is often claimed, ignores the effects of systematic state policy from the early 1990s. In 1996, the state support to establish new aided schools was withdrawn and in 2008 support for existing aided schools ended. Government schools faced significant budget cuts, teaching positions remained unfilled, schools and grade levels were merged to cope with the shortages, even cleaning staff were denied to schools and buildings were allowed to deteriorate. In our field research in Hyderabad, the harmful impact of state divestment from public schools was clearly evident. Studies show that 'the government's reduced priority toward providing sufficient resources to elementary education has indirectly increased the privatization of schools at elementary level' (Venkatnarayanan, 2015; Nambissan, 2010). Further, government schools are required to teach in the native language ${ }^{7}$ of the student, especially at the primary level. However, the shift towards a global outsourcing economy in India has led to burgeoning demand for

6 The 2016 union budget has allocated 4.9 per cent of GNP to education, but if one considers inflation and the GDP growth rate, the new budget is less than previous years. This does not meet the government's own target of 6 per cent of GNP for education (Tilak, 2006, 2009).

7 India is divided into linguistic states, hence medium of instruction varies by state. In a cosmopolitan city like Mumbai, government schools offer instruction in as many as nine languages. In Telangana and AP, medium of instruction in government schools is either Urdu or Telugu, the two dominant language groups in the region, though there is legal provision to offer instruction in Marathi and Gujarati as well. We believe no other country offers such linguistic diversity in its school system and affirms the importance of 'mother tongue' education especially in the early years of schooling. 
English only education that has led to even less demand for government schools (Lukose, 2009; Jeffrey, Jeffery and Jeffery, 2008; Faust and Nagar, 2001). These economic, social and political transformations of the last two decades have led to the proliferation of private 'English medium' schools across the country. And, while a national mobilization by educators and civil society groups to fulfill international norms related to universal basic education led to the promulgation of the Right to Education (RTE) Act in 2010, the Act permits private provision of education. Important to note here is that the RTE Act requires both private and public schools to fulfill minimal standards of quality education such as teacher certification, adequate physical infrastructure and operating on a not-for-profit basis. Advocates of quality education hoped that the legal mandates on private schools would curtail rampant commercialization and limit profit-seeking behaviour in education. However, our study and others find that the commercialization of education has continued apace and low fee schools function in flagrant violation of India's Right to Education Act. Furthermore, international investors have found ways to manoeuvre around the RTE Act by investing in the e-learning market and marketing edu-tech services and products to schools. The Indian case demonstrates that stronger and uncompromising legislation and enforcement are needed to prevent the commercialization and commodification of education as a whole.

In light of the above, it is not surprising that proponents of low-fee private schools (LFPS) are staunch opponents of the RTE Act and argue that these regulations prevent the poor from accessing education. Advocates of privatization promote LFPS as a cost-effective, profitable and economically viable way to universalize basic educational services, presenting them as a win-win formula for companies seeking a profit and for poor families wanting an education (Pearson, 2012; Tooley, Dixon and Gomathi, 2007; Jain and Dholakia, 2009). However, an estimated 37 per cent of the country's population live below the poverty line and cannot afford even the LFPS that are the cheapest private schools available (Government of India, 2009; Tilak, 2009; Nambissan, 2012b, 2014). On average, 30 per cent of household expenditure across different income categories is spent on private schooling, with the costs highest at the primary level (Tilak, 2009). Studies also show that all types of inequalities in household expenditure on education - by gender, rural-urban, household expenditure quintiles, and even 
by type of education - are the highest in primary education. This indicates that primary education being offered by different types of private and public schools in the country, tends to accentuate inequalities (Tilak, 2009; Mehrotra, 2005; Nambissan, 2014).

In critically assessing these multinational actors' claims to make schooling for the poor profitable while simultaneously promising quality education our research has shown that LFPS are not accessible for the very poor (Education International, 2016). This corroborates other studies that examine the socio-economic profile of families in LFPS to show that a significant proportion of rural and urban poor are unable to access LFPS (Goyal and Pandey, 2009; Härmä, 2011; Juneja, 2010). Furthermore, these schools fail to meet universal norms of quality education (Chudgar and Quin, 2012; Singh, 2015; Kelly, Krishna and Bhabha, 2016). Cost-cutting approaches include 'standardized and replicable processes to achieve economies of scale and allow rapid development' and 'leverage low-cost, high-impact technology' (Riep, 2015). Finally, the data on learning outcomes is mixed, with few rigorous studies showing superiority when control for socio-economic differences are taken into account (Woodhead, Frost and James, 2013; Singh, 2015; Kingdon and Theopold, 2008).

\section{HYDERABAD: HI-TECH CITY MEETS THE OLD CITY}

An important foundational part of our research has been to understand the networks and logics of global investors and corporations that are active in the edu-business sector in Hyderabad. Hyderabad, famously referred to as the Silicon Valley of the East, ${ }^{8}$ has made a name for itself as the destination of choice for the global IT economy. In 1997, the then Chief Minister of the state, Chandrababu Naidu, built Hi-Tech city, a 'software park' to provide state-of-the-art facilities and cheap labour for the global IT and outsourcing economy. Hi-Tech city has attracted leading software companies and multinational firms and has become a hub for both high-skilled labour such as software design and manufacturing and

8 Hi-Tech city is also an acronym for Hyderabad Information Technology Engineering and Consultancy. 
the relatively less-skilled business processing call centres (Biao, 2006; Upadhyay and Vasavi, 2008). Hyderabad is also known for its extensive network of for-profit post-secondary institutions that specialize in engineering and computer science, and that form the supply chain for Hi-Tech city (Biao, 2006; Kamat, 2011; Kamat, Hussain and Mathew, 2004; Upadhyay and Vasavi, 2008). Global multinationals such as Google and Microsoft have their country headquarters in the city, making it an attractive destination for global edu-businesses looking for commercially viable technologybased solutions in education. For PALF and other edu-investors, the availability of a huge pool of computer engineers and software workers from which to recruit prospective entrepreneurs makes Hi-Tech city of strategic importance to build the edu-solutions market.

Other parts of Hyderabad city are remarkably different from Hi-Tech city and its surroundings. The distance from the 'Old City' to Hi-Tech city is eleven miles but they are worlds away from each other. Hyderabad has a sizable Muslim population of 41 per cent, considerably higher than elsewhere in the country. 9 'Old City' Hyderabad has poorly maintained infrastructure, inadequate housing, water supply and electricity, and poor sewage and sanitation services. The streets are dotted with signs that advertise 'coaching centres' for Math and Science, spoken English tutorials, and corporate colleges that promise entry into a career in Hi-Tech city (Kamat, 2015). Most of these are poor and concentrated in the southwest part of Hyderabad, in and around the 'Old City', where James Tooley first discovered the LFPS that he promotes globally as the new model of schooling for the poor (Tooley, 2000, 2007). While accurate data on the number of LFPS is difficult to source, an estimated 1,300 of these exist in Hyderabad city alone (ASER, 2011).

Our study of the LFPS sector in Hyderabad reveals a complex well-networked assemblage of global actors that are in the business of education privatization and that stand to make a considerable profit from it. Two actors stand out as having launched the LFPS 'movement' in India. One is James Tooley from the University of

9 The city was the capital of the princely state of Hyderabad ruled by Muslim nobility for over two centuries and was never under direct British colonial rule. 
Newcastle, UK, a leading advocate of LFPS in India and several other countries in Asia and Africa. Tooley is currently Chairman of, and investor in, Empathy Learning Systems Pvt. Ltd. based in Hyderabad. The second influential actor is the global corporation, Pearson that operates in the LFPS sector through its philanthropic venture, PALF. Pearson is the world's largest multinational education corporation with operations in 70 countries worldwide and an extensive business portfolio that positions it as the world's leading education service provider. In an interview, PALF CEO Katelyn Donnelly confirmed that India is their 'first market before they expand to other countries'. ${ }^{10}$ For her, India is the right market to test products for the low-income segment because 'parents have shown a willingness to pay'. ${ }^{11}$ For promoters of the 'edu-solutions industry' Hyderabad's importance is underscored. A loan officer interviewed by the authors at the Indian School Finance Corporation (ISFC) that gives loans to LFPS expressed a similar sentiment: 'Hyderabad ... is a very welcoming market for innovations in education. So everything that we launch and develop, this is the right place for us to test and get its results and response.'

As a member of several global policy forums in education such as the Global Partnership for Education (GPE) and the Global Business Coalition for Education that it helped found, Pearson is able to influence and shape policy that complement its interests and investments. Pearson is active in emerging economies through PALF, a venture capital investment fund that 'makes significant minority equity investments in for-profit companies to meet the growing demand for affordable education across the developing world'. ${ }^{12}$ In recent years, PALF has invested in ten companies spanning five countries, and allocated its first fund of US $\$ 15$ million, with plans to invest a further US\$50 million in edusolutions companies in the next few years. According to their website, these companies are on 'an upward trajectory toward growth, profitability and better learning outcomes' ${ }^{13}$ And with the new technicist emphasis on 'social efficiency measures', PALF's investment arm has also capitalized on developing new market

10 Donnelly quoted in Moses (2013).

11 Donnelly quoted in Moses (2013).

12 https://www.affordable-learning.com. Accessed on 5 May 2016.

13 https://www.affordable-learning.com. Accessed on 5 May 2016. 
products and software for measuring accountability and learning outcomes, which they 'apply rigorously to every investment'. ${ }^{14}$

PALF was the primary investor in Omega Schools, a chain of LFPS in Ghana of which James Tooley is co-founder and Chairman of the Board. Omega Schools is regarded as a pioneer in the 'pay as you go' model (meaning access to school each day is conditioned on the learner arriving with payment) that has attracted many investors but is deeply problematic in terms of access and equity in education (Riep, 2015). PALF has also recently cultivated more major international supporters and donors such as Save the Children and large impact investors like Omidyar Network (n.d.). The Michael and Susan Dell Foundation have also recently co-invested with PALF.

Importantly, a significant part of the pro-privatization research that makes a case for technology-based schooling was authored by Tooley and his associates using data from schools in Hyderabad that are clients or affiliates of Tooley's company, Empathy Learning Systems, and/or are commissioned by Pearson and other pro-market international firms and think tanks (Tooley, 1999, 2007; Tooley and Dixon, 2003; Tooley, Dixon and Gomathi, 2007; Tulloch, Kramer and Overby, 2014). A significant finding from our study is that efforts to scale up these LFPSs and generate higher revenues from these schools in Hyderabad have not been successful. As a result we anticipate that these will eventually be replaced by multinational school chains (like Bridge International Academies [BIA]) that offer economies of scale through standardization and technology, enabled by sizeable global investments. The recent MOU between Chief Minister Chandrababu Naidu and Bridge International Academies, to run the state's government schools is perhaps a sign of things to come.

In addition, there are a growing number of actors and institutions involved in the promotion and expansion of LFPS including, for instance, the World Bank and the UK Department for International Development (DFID), the International Finance Corporation (IFC), think tanks, and foundations such as the John Templeton Foundation, the Bill and Melinda Gates Foundation, the Michael and Susan Dell Foundation, venture capitalists such as Gray Matters

14 https://www.affordable-learning.com. Accessed on 5 May 2016. 
Capital, and private equity firms such as Kaizen Management. ${ }^{15}$ Our research in Hyderabad pointed to PALF as a leader of the edu-business industry, in partnership with a diverse group of corporate foundations, investors, and entrepreneurs that suggests an emergent Global Education Industry (GEI) in India.

The hugely profitable global market of edu-solutions industry through multinational corporations, philanthropic groups and global governance organization has been well documented elsewhere (see, for instance, Junemann and Ball, 2015; Olmedo, 2013; Hogan, Sellars and Lingard, 2015; Verger 2016), but to briefly reiterate, the worldwide spending on education currently tops US\$4 trillion, a figure that is expected to rise dramatically. Companies poised to benefit from these opportunities - content and assessment providers like Pearson, firms like mobile networks, and companies that provide the toolkits, software and tablets, have been focusing on these products for years, with the Indian tech industry a key developer and recipient (Cave and Rowell, 2014a). Multinational technology giants are positioned to exploit these opportunities.

What has been under-theorized is how tech giants are replacing or providing the same services that a national government would: data management, assessment systems, curricula, teacher training, online courses, and virtual schools. Early adopters receive benefits and incentives to use these inter-linking products on a trial basis at a lower cost. Over time the need for schools to purchase more products or services, or update their products increases, so does the profitability. This market is predicted to be worth US\$75 billion worldwide by 2020 . For example, the mobile education market is ripe for expansion in India, particularly in rural or urban slum areas where access to reliable Internet service or computers is limited. The market for devices like tablets is set to be worth US\$32 billion. Among the global tech giants are Microsoft, Google, and, more recently, News Corp's Amplify. Importantly, these multinational

15 Some of the other players are the World Bank, Global Partnership for Education, Global Business Coalition for Education, the Business Backs Education campaign, and the Centre for Educational Innovations. A more recent phenomenon is the emergence of homegrown private foundations investing in education such as Azim Premji Foundation, Naam Foundation, Central Square Foundation, and the Naandi Foundation. These Indian foundations may have varying perspectives on the importance of public education and for-profit investments in education. See, for instance, Dhankar (2016). 
corporations are not merely benignly selling products and services to open markets; they are also actively engaged in lobbying for policies that benefit their bottom line, with considerable money and effort invested that is scaled to the market sector.

\section{THE PERFECT CON: INDIA'S POLICY ENTREPRENEURS}

What has in the past often been overlooked in scholarly research 'following the money' of multinational corporations is how these new globally networked organizations are also increasingly influencing education policy. Through hiring and promoting "policy entrepreneurs', they can conduct research and write policies to serve their interests with tremendous financial and political leverage, and use their bargaining power to set the rules (see Robertson, $2008,2005)$. We argue that this is the educational equivalent to a 'ponzi scheme' - much like predatory market makers, multinational edu-preneurs try to create demand for fee-based schools, seducing parents and the poor families who desperately desire quality education (and subsequently believe in upward mobility through private technology-based schooling), and selling the idea that low-fee schools (with tech-based bells and whistles) will provide just that. In the context of education these promises haven't improved education quality.

According to Nambissan and Ball (2011), policy entrepreneurs are 'deeply embedded' in the infrastructure of neoliberal organizations internationally and locally with access to transnational advocacy networks with large financial resources. These social links form powerful and influential ties - for example, Pearson's chief education adviser, Sir Michael Barber, was a former top aide to former UK prime minister Tony Blair and 'an old friend of Tooley from when they taught in Zimbabwe together years ago' (Srivastava, 2016). What has emerged are new categories for understanding policy change within these market-making institutions. Traditional understandings of how policies and decisions are made by the state in relation to education systems do not hold for these new global policy relationships between, for instance, local entrepreneurs, corporate philanthropists and global business 
executives, or the ways ideas and educational solutions are generated within and across global multilateral and financial institutions, rather than through educational planners and ministries.

In Hyderabad, PALF and other financiers also attempt to work through local private school federations to pressure the government to provide an amenable environment for their activities. Through public-private partnerships (PPPs), the government is encouraged to dismantle regulatory hurdles and implement policies that incentivize low-cost private schools, encourage the creation of new companies that offer products and services to schools, and foster NGO networks to act as service providers and intermediaries providing training, curricula, and data management and monitoring systems. The financing of PPPs relies largely on government subsidies, transferring funding from the public to the private sector. This situation in turn has resulted in the establishment of a plethora of microfinance providers, impact investors, and development finance institutions joining into the edu-solutions market in the hopes of bringing additional private capital (at high interest rates) to local private education providers.

As previously mentioned, much of this philanthropic engagement has been in conjunction with other non-state private actors or through PPPs, particularly in relation to efforts aimed at universalizing education beyond basic levels (Fengler and Kharas, 2010; Srivastava and Oh, 2010). Srivastava (2016) provides an extensive overview of several foundations and corporate philanthropy in education operating across India. She noted significant differences among them with, for example, organizations like the Azim Premji Foundation, a relatively new player, alongside older more established organizations like the Sir Ratan Tata Trust. In addition, domestic foundations were operating alongside international ones (e.g., Hewlett, MasterCard) with different regulatory and reporting requirements. Some operate as funders seeing a return on their investments, while others operate in the traditional mode of a charitable trust.

Corporate philanthropic-type activities have also been spurred by the government's new Companies Act 2013 which mandates corporate expenditures of 2 per cent on corporate social responsibility (CSR) activities for companies above a certain income threshold (Government of India, 2013). According to findings from Ernst \& Young, the CSR covers about 2,500 companies and has generated 
US $\$ 2$ billion in funds (Government of India, 2013). There are numerous other international actors with significant interest in promoting private sector approaches in education. For instance, data from the US-based Foundation Center reveals that India ranked sixth in receiving grants from the top 1,000 US private foundations, having attracted over US\$831 million between 2001 and 2011 (Government of India, 2013). The big picture setting within which the growing 'philanthro-capitalism' that is emerging can be traced through the links and connections between corporations, venture capitalists, private foundations and, increasingly, governments. Extending on Ball (2008) and Olmedo's (2013) conceptualization of 'philanthropic governance', Srivastava (2016: 8) suggests:

The primacy of market-based solutions in education espoused by the new global philanthropy (e.g. competition, choice and narrowly defined assessment metrics) and the simultaneous use of complex multistakeholder partnerships and PPPs, open up and create formal and non-formal spaces for constellations of philanthropic and other nonstate private actors. These fundamentally alter education governance by surreptitiously embedding forms of privatization in education systems, though this may not be the intention of all actors involved.

As elaborated in more detail in our report, Hyderabad's new pro-privatization education policy networks are 'facilitated by international and multilateral agency discourse and a broader discourse of the knowledge economy and the "global Silicon Valley," often promoted as pathways to "quick" economic development' (Educational International, 2016; Srivastava, 2013: 9; see also Biao, 2006; Kamat, Hussain and Mathew, 2004). This ideology is based on the 'magic of the market' and increasingly influences the current global policy landscape (driven primarily by US and UK companies and interests). In the education sector, this has led to the prioritization of narrow technical solutions for education, including decontextualized and impetuous policy borrowing as well as the transfer of a limited set of policy options.

Private-sector providers operate through spreading and advancing market ideology in education by incentivizing investment funds, providing corporate training camps on market modelling and largescale financing, and various crowd-sourcing and edu-preneur meet-up exhibitions (Education International, 2016). Many of the 
edu-preneurs we spoke to referred to this as developing an 'ecosystem' that facilitates networks and connections between investors, entrepreneurs, a relatively cheap tech-savvy labour force, a lowpaid teaching force, and the LFPS, all in close proximity with one another. This ideology is fostered through powerful rhetoric and promises, such as the opportunity to participate in leadership development institutes and crowd sourcing/fundraising events. As part of this discourse, local school proprietors are renamed 'edupreneurs' creating knowledge solutions, developing educational ecosystems, offering customized/personalized or individualized learning environments, advocates of parental choice/vouchers, or pioneers uncovering hidden markets.

In this 'ecosystem', global actors coordinate and cooperate with one another to maximize their investment portfolios while deepening competition among local edu-preneurs who rival with one another to develop the most marketable product or service. The presence of an information technology industry and the willingness of government to pay for products and services has been an essential part of the business model being pursued. Replicating a 'start-up' business model, edu-businesses appear intent to test and incubate new products and services, develop new models of forprofit schools, and market new products and services, charging high interest loans and start-up funds for franchises.

On the contrary, our research findings discuss the teaching and learning conditions in LFPS, issues of increasing inequalities based on gender discrimination and social exclusion, and the deprofessionalization of teachers as a result of privatization. Related studies of low-fee private schools elsewhere suggest similar findings. For example, Bridge International Academies has come under heavy criticism in Uganda and Kenya for its scripted curriculum and dependence on untrained teachers.

\section{PRIVATIZATION UNDERMINES THE RIGHT TO EDUCATION}

In the context of the many challenges that confront public education systems globally, the increasing commercialisation and privatisation in and of education represent the greatest threat to education as a public good and to equality in education access and outcomes. (See Education 
International's Global Response Against the Commercialization of Education, 2015 for an overview of the argument.) ${ }^{16}$

Privatization in and of education runs counter to the goal of human rights-based, inclusive education. Already marginalized and vulnerable groups, including women and girls, are more disadvantaged by private education provision because they are the least likely to be able to pay for services. ${ }^{17}$ Elsewhere we have argued that the growth of LFPS is directly related to the government's failure to meet its constitutional responsibilities and its obligations under the RTE Act as well as its international obligations to provide free quality education as a fundamental human right. It is therefore an urgent priority that the governments at the state and federal levels reinvest in public education and support all schools to deliver quality education.

Our study of the private education sector in India revealed a complex well-networked assemblage of global actors that are invested in the business of privatization of education, and who stand to make a considerable profit from it. In addition to the two actors who launched LFPS in India, James Tooley and the global corporation Pearson, other actors and institutions are involved. ${ }^{18} \mathrm{We}$ critically assessed these multinational actors' claims to make schooling for the poor profitable while simultaneously promising quality education. We demonstrated that the schools have been unprofitable despite the expectations of companies, and they have also failed to deliver anything close to quality education.

Contrary to supporters' claims, we found that low-fee private schools operate with untrained and unqualified teachers who are paid subsistence wages in an environment that has no accountability. There is growing alarm that LFPS are eroding the employment

16 Retrieved from https://www.unite4education.org/about/a-global-response-toeducation-commercialisation/ on 20 May 2018.

17 Right to Education Discussion Forum, 'Privatisation and its Impact on the Right to Education for Women and Girls', written submission to the UN Committee on the Elimination of Discrimination Against Women (CEDAW), 7 July 2014.

18 Some of the other players are World Bank, Global Partnerships for Education, the Global Business Coalition for Education, the Business Back Education campaign, and the Centre for Educational Innovations. A more recent phenomenon over the last ten years or so is homegrown private foundations in education with large endowments such as APF, Naam Foundation, and Nandi Foundation. 
protections and training requirements for teachers (Azam and Kingdon, 2013). Classrooms and overall facilities of the 12 schools we visited in Hyderabad were extremely crowded with about 40 students in a $4 \times 4 \mathrm{~m}$ room with little or no ventilation. Most buildings were not built to house several hundred (and often up to 1,000 students) so toilets were inadequate, compounding the heavy odours in the hot, airless and overcrowded classrooms. Minimizing costs and maximizing efficiency means that, to keep enrolment at target rates, every space was used for classrooms, leaving no space for laboratories, gyms or libraries. Open areas for play and sports were virtually non-existent, which all schools are required to have under the RTE legislation. Teachers met and had lunch in small and cramped staff rooms (if available). The key cost-saving factor that sets low-cost private schools apart from public schools is their practice of hiring untrained teachers, almost all of whom are women. This practice allowed the schools to keep fees low and hire a larger number of teachers. LFPS teacher salaries are about US\$54 per month with no pension or benefits, less than one-quarter of public schools teachers' salaries. ${ }^{19}$ Only 14 per cent of teachers have post-graduate qualifications and rote learning is prevalent. This is contrary to the claims of advocates of LFPS that teaching is better - more innovative and interactive, and who equate the use of technology with independent work and problem solving. Yet what we observed in these schools was rote and didactic learning read from a script or tablet.

One of the most distinguishing characteristics of the LFPS is big differences in teachers' wages between government and low-cost private schools. The precarious and vulnerable positioning of casualized and low-waged work for a predominantly female teaching

19 Availability of teachers in schools is an important variable for quality education. In 2011, there were about 6.7 million teachers engaged in teaching in schools imparting elementary education in the country. All the schools in the country now have an average of three or more teachers. The percentage of teachers in Government schools was 64.13 per cent in 2011-2012 as compared to 65.55 in 2010-2011, making the total of teachers in Government schools over 430,000. The percentage of teachers in government-aided schools is 8.06, showing a decline since 2006-2007, when it was 11.25 per cent. The total number of private teachers in India is above 200,000 while the total number of teachers in madrassas is over 180,000. The total number of primary school teachers is over 250,000 (Center for Education Innovations, 2015. Results for Development Report. Retrieved from: educationinnovations.org). 
force constitutes gender discrimination. Female private school teachers are expected to only supplement the household income and their tenure is seen to be temporary because of possible migration after marriage or resignation following pregnancy or childbirth. LFPS are plagued with constant teacher turnover, and demands and measures for quality underscore the need for more training and support in content and teaching methods for this revolving door of teachers. The edu-solutions market in India does offer online teacher training so young women can be trained and tested, but in their own time.

Moreover, the professional autonomy and rights of teachers, as well as the local control of communities over their schools, has been undercut by the shift in authority to private, corporate, and global actors. Similarly, it is reasonable to question whether the shift in accountability structures away from democratic modes to corporate/consumer arrangements reshapes the orientation of education as a public good. That is, corporations are legally accountable primarily to their stockholders and must work first and foremost to create returns for those investors, which are not necessarily aligned with those of the customers, that is, the students, their families, or their communities.

Education can and should play an essential role in addressing structural and systemic inequality. It is the foundation on which poor, marginalized or vulnerable groups are able to realize their rights and aspirations and participate meaningfully in a democracy. However, the increasing reliance on private provision to fulfill the right to education creates a cycle wherein the poorest and most marginalized have diminishing access to quality education. ${ }^{20}$ Moreover, the commercialization and marketization of education by global finance directly contradicts the provision of education as a human right. To achieve the promise of universal quality education, states must provide quality accessible, free public schooling so parents aren't forced to choose between their daughters or sons, or choose whether to feed their families or pay for school. Rather than attempting to transfer or deflect their responsibility to private providers, states must take the opposite approach and meet their

20 Center for Education Innovations, 2015. Results for Development Report. Retrieved from: educationinnovations.org, p. 11. 
obligations to fulfill and provide free quality education that is available and accessible to all.

\section{REFERENCES}

Annual Status of Education Report (ASER) (2011). ASER Center, Pratham: New Delhi, 16 January 2012. Retrieved from http://img.asercentre.org/docs/ Publications/ASER\%20Reports/ASER_2011/aser_2011_report_8.2.12.pdf on 22 May 2018.

Azam, M. and Kingdon, G.G. (2013). Are girls the fairer sex in India? Revisiting intra-household allocation of education expenditure. World Development, 42, 143-164.

Ball, S.J. (2008). New philanthropy, new networks and new governance in education. Political Studies, 56(4), pp. 747-765.

Biao, X. (2006). Global 'Body Shopping': An Indian Labor System in the Information Technology Industry. Princeton, NJ: Princeton University Press.

Bridge International Academies (BIA) (n.d.). Company [Investors]. Retrieved from: http://www.bridgeinternationalacademies.com/company/investors/ on 8 March 2014 and 2015.

Cave, T. and Rowell, A. (2014a). A Quiet Word: Lobbying, Crony Capitalism and Broken Politics in Britain. New York: Random House.

Cave, T. and Rowell, A. (2014b). The truth about lobbying: 10 ways big business controls government. The Guardian, 12 March 2014.

Chatterji, D. (2010). PEs pump in \$140 million in education since Jan 2010. Economic Times, 19 May 2010. Retrieved from http://articles. economictimes.indiatimes.com/2010-05-19/news/27599487_1_pe-investmenteducation-sector-idfc-private-equity on 20 May 2018.

Chudgar, A. and Quin, E. (2012). Relationship between private schooling and achievement: results from rural and urban India. Economics of Education Review, 31(4), pp. 376-390.

Dhankar, R. (2016). A lesson in hidden agendas. The Hindu, 26 March YEAR. Retrieved from http://www.thehindu.com/opinion/lead/a-lesson-in-hiddenagendas/article8397088.ece on 15 May 2016.

Education International (2016). Profiting from the poor: the emergence of multinational edu-businesses in Hyderabad India by S. Kamat, C.A. Spreen and I. Jonnalagadda. Brussels, May 2016.

EdWeek Market Brief (2013). Global education market tops \$4 trillion, analysis shows. Article dated 7 February 2013. Retrieved from https://market brief.edweek.org/marketplace-k-12/size_of_global_e-learning_market_44_ trillion_analysis_says/ on 4 June 2018.

Faust, D. and Nagar, R. (2001). English medium education, social fracturing, and the politics of development in postcolonial India. Economic and Political Weekly, 28 July 28 to 3 August, pp. 2878-2883.

Fengler, W. and Kharas, H.J. (eds) (2010). Delivering Aid Differently: Lessons from the Field. Cambridge, MA: Brookings Institution Press. 
Government of India (2009). Report of the Expert Group to review the methodology of estimation for poverty. Suresh Tendulkar Committee, Planning Commission of India, New Delhi, November.

Government of India. (2013). Twelfth Five Year Plan (2012-2017), Volume 3: Social Sectors. New Delhi: Sage. Retrieved from http://planning commission.nic.in/plans/planrel/fiveyr/12th/pdf/12fyp.vol3pdf on 10 May 2016.

Goyal, S. and Pandey, P. (2009). How do government and private schools differ? Findings from two large Indian states. South Asia Human Development, World Bank. Retrieved from http://wwwwds.worldbank.org/external/ default/WDSContentServer/WDSP/IB/2010/01/11/000333038_201001110 on 12 January 2018.

Härmä, J. (2009). Can choice promote Education for All? Evidence from growth in private primary schooling in India. Compare, 39(2), pp. 151-165.

Härmä, J. (2011). Low cost private schooling in India: is it pro poor and equitable? International Journal of Educational Development, 31, pp. 350s356s.

Hogan, A., Sellar, S. and Lingard, B. (2015). Network restructuring of global edu-business. In W. Au and J.J. Ferrare (eds) Mapping Corporate Education Reform. Power and Policy Networks in the Neoliberal State. London: Routledge, pp. 43-64.

India Brand Equity Foundation (2016). India Education Sector Outlook. India Brand Equity Foundation. Retrieved from http://www.ibef.org/industry/ education-sector-india.aspx on 20 May 2018.

Jain, Pankaj S. and Dholakia, R.H. (2009). Feasibility of implementation of Right to Education Act. Economic \& Political Weekly, 44(25), pp. 38-43.

Jeffrey, C., Jeffery, P. and Jeffery, R. (2008). Degrees Without Freedom: Education, Masculinities and Unemployment in North India. Stanford, CA: Stanford University Press.

Juneja, N. (2010). Access to what? Access, diversity and participation in India's schools. CREATE Pathways to Access, Research Monograph No. 32. Retrieved from http://www.create-rpc.org/pdf_documents/PTA32.pdf on May 20, 2018.

Junemann, C. and Ball, S.J. (2015). Pearson and PALF: the mutating giant. Education International, Brussels. Retrieved from https://www.unite4 education.org/resources/unclassified/pearson-and-palf-the-mutating-giant/ on 18 May 2016.

Kamat, S. (2011). Neoliberal urbanism and the education economy: producing Hyderabad as a 'Global City'. Discourse: The Cultural Politics of Education, 32(2), pp. 187-202.

Kamat, S. (2015). Inequality in education. Seminar Issue 672, Special Issue on Emerging Patterns of Inequality in India, August. Retrieved from http:// www.india-seminar.com/2015/672.htm on 13 March 2016.

Kamat, S., Hussain, M.A. and Mathew, B. (2004). Producing hi-tech: globalization, the state and migrant subjects. Globalization, Societies and Education, 2(1), pp. 5-23. 
Kelly, O., Krishna, A. and Bhabha, J. (2016). Private schooling and gender justice: An empirical snapshot from Rajasthan, India's largest state. International Journal of Educational Development, 46, 175-187.

Kingdon, G.G. and Theopold, N. (2008). Do returns to education matter to schooling participation? Evidence from India. Education Economics, 16(4), pp. 329-350.

Lukose, R. (2009). Liberalization's Children: Gender, Youth, and Consumer Citizenship in Globalizing India. Durham, NC: Duke University Press.

Mehrotra, S. (ed.) (2005). The Economics of Elementary Education: The Challenge of Public Finance, Private Provision and Household Costs. New Delhi: Sage.

Moses, N. (2013). India will be our first market for PALF. Online 20 July 2013. Retrieved from http://social.yourstory.com/2013/07/pearsons-donnellyindia-will-be-our-first-market-for-the-pearson-affordable-learning-fund-beforewe-expand-to-other -countries/ on 5 May 2016.

Nambissan, G. (2010). The global economic crisis, poverty and education: a perspective from India. Journal of Education Policy, 25(6), pp. 729-737.

Nambissan, G. (2012a). Private schools for the poor: business as usual? Economic and Political Weekly of India, xlvii(4), pp. 51-58.

Nambissan, G. (2012b). Low cost private schools for the poor in India: some reflections. In India Infrastructure Report 2012: Private Sector in Education. India Infrastructure Report 11. New Delhi, India: Routledge. Retrieved from http://www.idfc.com/pdf/report/2012/Chapter_8.pdf on 6 May 2016.

Nambissan, G. (2014). Poverty, markets and elementary education in India. Working Paper no. 3 Transnational Research Group, German Historical Institute, London. Retrieved from http://www.perspectivia.net/publikationen/ trg-working-papers/nambissan_markets on 6 June 2016.

Nambissan, G. and Ball, S.J. (2011). Advocacy networks, choice and private schooling of the poor in India. In M. Lall and G.B. Nambissan (eds), Education and Social Justice in the Era of Globalization: Perspectives from India and the UK. New Delhi: Routledge, pp. 161-180.

Nayyar, D. (2008). Liberalization and Development. Delhi: Oxford University Press.

Olmedo, A. (2013). Policy-makers, market advocates and edu-businesses: new and renewed players in the Spanish education policy arena. Journal of Education Policy, 28(1), pp. 55-76.

Omidyar Network (n.d.). Portfolio [Bridge International Academies]. Retrieved from http://www.omidyar.com/portfolio/bridge-international-academies on 8 March 2014.

Oxfam International (2014). Working for the Many: Public Services Fight Inequality. Oxford: Oxfam.

Pearson (2012a). Annual Reports and Accounts. London: Pearson.

Riep, C. (2015). Omega schools franchise in Ghana: a case of 'low-fee' private education for the poor or for-profiteering? Working Paper No. 63, Open Society Foundation. 
Robertson, S. (2008). The new global governance paradigm in education: public-private partnerships and social justice. Education and Development Working Paper, No. 6. IS Academie, University of Amsterdam. Retrieved from http://educationanddevelopment.files.wordpress.com/2008/06/slr_wp6. pdf on 10 May 2016.

Robertson, S.L. (2005). Re-imagining and rescripting the future of education: global knowledge economy discourses and the challenge to education systems. Comparative Education, 41(2), pp. 151-170.

Shinde, S. (2013). Indian education sector market size to be $\$ 110$ bn by FY15. Business Standard, 21 June 2013. Retrieved from http://www.businessstandard.com/article/companies/indian-education-sector-market-size-to-be110-bnby-fy15-113012100537_1.html on 20 May 2018.

Singh, A. (2015). Private school effects in urban and rural India: panel estimates at primary and secondary school ages. Journal of Development Economics, 113, 16-32.

Spreen, C.A. and Vally, S. (eds) (2014). Privatization: selling out the right to quality public education for all. In OurSchools/OurSelves, Canadian Center for Education Policy Alternatives, Summer 2014.

Srivastava, P. (2013). Low-fee private schools: issues and evidence. In P. Srivastava (ed.), Low-fee Private Schooling: Aggravating Equity Or Mitigating Disadvantage? Oxford, UK: Symposium Books, Chapter 1.

Srivastava, P (2016). Philanthropic engagement in education localised expressions of global flows in India. Contemporary Education Dialogue, 13(1), 5-32.

Srivastava, P. and Oh, S.A. (2010). Private foundations, philanthropy, and partnership in education and development: mapping the terrain. International Journal of Educational Development, 30(5), 460-471.

Tilak, J. (2006). On allocating 6 percent of GDP to education. Economic and Political Weekly of India, 18 February 2006, pp. 613-618.

Tilak, J. (2009). Household expenditure on education and implications for redefining the poverty line in India. Unpublished paper. Delhi: NUEPA.

Tooley, J. (1999). The Global Education Industry: Lessons From Private Education In Developing Countries. London: Institute of Economic Affairs.

Tooley, J. (2000). Private education: the poor's best chance? UNESCO Courier, 53(11), p. 24.

Tooley, J. (2007) Private schools for the poor: education where no one expects it. Education Next, 5(4). Retrieved from http://educationnext.org/private schoolsforthepoor/ on 8 May 2016.

Tooley, J. and Dixon, P. (2003). Private Schools for the Poor: A Case Study from India. Reading: CfBT. Retrieved from http://www.isfc.in/tooley_ hyderabad_study.pdf on 20 March 2016.

Tooley, J., Dixon, P. and Gomathi, S.V. (2007). Private schools and the Millennium Development Goal of universal primary education: a census and comparative survey in Hyderabad, India. Oxford Review of Education, 33(5), pp. 539-560. 
Tulloch, J., Kramer A. and Overby, L. (2014). Private schools for the poor: educating millions in the developing world. Our Next Endeavour, Working Paper 3. Berlin: Endeva.

Upadhyay, C. and Vasavi, A.R. (2008). In an outpost of the global economy: work and workers in India's information technology industry. In C. Upadhyay and A.R. Vasavi (eds), In an Outpost of the Global Economy: Work and Workers in India's Information Technology Industry. New York: Routledge, pp. 7-48.

Varma, S. (2017). Share of spend in government expenditure, GDP on education falling for 3 years. Times of India, 6 February. Retrieved from https://timesofindia.indiatimes.com/india/share-of-spend-in-governmentexpenditure-gdp-on-education-falling-for-3-years/articleshow/56991039.cms on 20 May 2018.

Venkatnarayanan, S. (2015). Economic Liberalization in 1991 and its Impact on Elementary Education in India. Sage Publications, Volume 5, Issue 2, published online 19 June 2015. Open Access. Retrieved from http:// journals.sagepub.com/doi/abs/10.1177/2158244015579517 on 6 January 2018.

Verger, A. (2016). The rise of the global education industry: some facts, concepts and figures. Unite for Quality Education, Education International. Retrieved from https://www.unite4education.org/global-response/the-rise-ofthe-global-education-industry-some-concepts-facts-and-figures/ on 11 December 2017.

Woodhead, M., Frost, M. and James, Z. (2013). Does growth in private schooling contribute to Education for All? Evidence from a longitudinal, two cohort study in Andhra Pradesh, India. International Journal of Educational Development, 33(1), pp. 65-73. 